\title{
Economic Analysis of Cassava Production: Prospects and Challenges in Irepodun Local Government Area, Kwara State, Nigeria
}

\author{
S. O. Sanusi ${ }^{\text {a, }}$, I. A. Adedeji ${ }^{\text {b }}$, M. J. Madaki ${ }^{\text {c }},{\text { G. } \text { Udoh }^{\text {d }} \text {, Z. Y. Abdullahi }}^{\text {e }}$ \\ a, b, c Department of Agricultural Economics and Extension, Federal University, Gashua, P.M.B 1005, Yobe State, Nigeria \\ ${ }^{d}$ Department of Agricultural Economics and Extension, Landmark University, Oro-Omuran, Kwara State, Nigeria \\ ${ }^{e}$ Department of Agricultural Economics and Extension, Kano University of Science and Technology, Wudil, Kano State, Nigeria
}

\section{Authors' Contributions}

This work was carried out in collaboration between authors. S. O. Sanusi: conceptualization of the study and development of the research plan, coordination of entire research activities, and preparation of the manuscript with contributions from the team. I. A. Adedeji: coordination and supervision of data collection process, development of the methodology for the research work and data analysis. M. J. Madaki \& Z. Y. Abdullahi: data entries and coding, and manuscript proof reading and editing. G. Udoh: data collection and presentation, and support analysis of data. The revised manuscript was read and approved by all authors.

\section{ARTICLE INFO}

\section{Article history:}

Received 25 October 2020

Received in revised form

18 November 2020

Accepted 25 November 2020

Available online

29 November 2020

Keywords:

Cassava production Economic analysis Gross margin

Nigeria

Regression model

\section{ABSTRACT}

This study was carried out to analyse cassava production, prospects and challenges in Irepodun local government area, Kwara State, Nigeria. It aimed to examine the determinant variables and determine the profitability level of cassava enterprises. The study was based on primary data obtained with the aid of structured questionnaire from 100 cassava farmers drawn through multi-stage sampling techniques from the study area. Data were analysed using descriptive statistics, ordinary least square (OLS) regression model and gross margin analysis. The result of the OLS regression estimates showed that farm size, cost of fertilizer application, farm size, herbicides, family and hired labour were significant variable affecting cassava production in the study area. Fertilizer, farm size and hired labour are significant at $1 \%$ while herbicide and family labour are significant at $10 \%$. The study found that the average gross margin per hectare for cassava production in the study area was $\$ 24,749.28$ (\$65.30) with a gross benefit ratio of 1.38. This shows that for every 1 invested in the business of cassava production, there is a corresponding profit of 1.38 . The major challenges identified in cassava enterprise are huge transportation cost, high cost of production, lack of improved cassava cultivars, and lack of market linkages. The study concluded despite the problem encountered in the study area, cassava production is profitable and can serve as a panacea for economic improvement of households. Therefore, the study recommends that basic inputs such as improved cassava varieties, herbicides and fertilizer should be made available at affordable price. Also, infrastructural facilities such as good road network and improve marketing channels should be provided in order to sustain current cassava production rate and economic gains from the production.

\footnotetext{
* Corresponding author

E-mail address: sanusisaheed@yahoo.com
}

2756-6773 / (C) 2020 the authors. Published by Sciengtex. This is an open access article under CC BY-NC-ND license (http://creativecommons.org/licenses/by-nc-nd/4.0/) 


\section{Introduction}

Nigeria dependent on crude oil as a major source of revenue is mainly due to the fact that over $90 \%$ of its income is derived from oil and gas exploration [1]. Ever since the discovery of the crude oil, it has weakened the development and growth of other sectors in the economy particularly agricultural production. This situation has led to over reliance on oil, which can no longer sustain the growing population and the needed infrastructural facilities required to bring the nation to the level expected by her citizen. Hence, it is critical for the nation to look into agricultural business and harness the opportunity for feeding her fastgrowing population as well as enjoy the financial returns from the food markets [2]. Nigeria is an agrarian society with about $70 \%$ of her over 180 million population engaged in agricultural production [3]. Cassava (Manihot Esculenta) is a woody shrub of spurge family, Euphorbiaceae. It is extensively cultivated as an annual crop in tropic and subtropical regions for its edible starchy tuberous root, a major source of carbohydrates. Cassava when dried and grinded to powdery form called cassava flour serves as a major diet in different part of the country. It is one of the most drought tolerant crop capable of growing on soils with limited nutrients. Nigeria is currently the largest producer of cassava in the world though with fragmented industry structure and with an annual production of over 54 million tonnes of tuberous roots [4]. According to [5], cassava products have many uses apart from food. Some of the uses are animal feeds production, pharmaceutical and industrial production and for security uses. In specific terms [6] identified important areas where cassava products are playing leading role nationally and globally. The areas are medical and industrial alcohol, flour for bakery industries, sweeteners from cassava glucose and fructose for fruit juice industries. Other areas of use according to [7], [8] are distillation for beverage, cassava chips and as fillers in manufacturing of pharmaceutical tablets.

Cassava is important not only as a food crop but even more so a major source of income for rural households. As an income crop, cassava generates cash income for the largest number of households' comparison with other staples in the same category. As a food crop, cassava has some inherent characteristics, which make it attractive especially to the smallholder farmers in Nigeria. First, it is rich carbohydrates especially starch and consequently has a multiplicity of end uses. Secondly, it is available all year round, making it preferable to other more seasonal crops such as grains, peas, beans, and other crops for food security, energy security, poverty reduction and has economic importance for millions of smallholders in developing countries including Nigeria [9]. Despite the country huge comparative advantage in cassava production, Nigeria is not a major player in the global market of cassava value products [10]. The country is yet to fully utilise the abundant potentials of cassava as a major contributor to Gross Domestic Product (GDP) next to crude oil [11]. This is because the high production and processing cost, transportation and infrastructural deficits make it difficult to add value to cassava in terms of quantity, quality, shelf life and safety, which encourages export and in turn increases the GDP of the country.

Apart from considering the fact that rapid population growth tends to increase market demand, it would be justifiable to have adequate understanding of the operations surrounding cassava production being one of the most important crops in the country. This research work is expected to enhance farmers' resource allocation so as to achieve optimal goal within the limited available resources. The outcome of this research will also be of immense benefit to stakeholders in agricultural industry particularly policy and decision makers in order to achieve the target of the agricultural revolution and food security that are key for successful diversification of the economy. The significant role plays by agriculture particularly cassava production in the process of economic growth and development cannot be over emphasised. However, the myriad of problems confronting rural farmers that engaged in cassava production to meet up with the rising level of local population and demand need to be well understood. Similarly, in the view of [12], challenges facing medium and large-scale entrepreneur in the agricultural food production targeting local markets and export should be closely monitored for consistence growth and development. Therefore, the main purpose of this research is to analyse cassava production, prospects and challenges in Irepodun Local Government Area (LGA), Kwara State, Nigeria. The specific objectives are to:

(a) analyse the determinant variables in cassava enterprise;

(b) determine the profitability level of production; and

(c) examine the challenges associated with cassava production.

\section{Materials and Method}

The study area of this research was Irepodun LGA, Kwara State. It shares boundary with Ifelodun LGA to the North, Osun State to the South, Ekiti and Offa LGAs to the East and West respectively. It has a population of 148,610 people and a landmass of 1,095 square kilometres [13]. It is endowed with savannah 
and rain forest vegetations on a plain terrain with patches of rivers and streams. The people of the area are predominantly farmers and speak Yoruba language.

Multi-stage random sampling technique was employed in the present study. A total of one hundred (100) cassava farmers were randomly selected from the numerous towns and villages in the study area. Primary data were obtained by the use of interview schedule and structured questionnaires administered to the respondents. Data were analysed using descriptive statistics such as frequency, percentage and tables, budgetary techniques (cost and return/ gross margin analysis) and multiple regression model. The gross margin model used is as follows:

$\mathrm{GMc}=\mathrm{GIc}-\mathrm{TVCc}$.

GMc $=$ GIc - TVCc $(N / h a)$.

$\mathrm{BCR}=\mathrm{GMc} / \mathrm{TVCc}$.

Where, GMc is the gross margin of cassava output ( $\mathrm{N} / \mathrm{ha})$, GIc is the gross income of cassava output ( $\mathrm{N} / \mathrm{ha})$, which is the product of the total output and the unit price of output, TVCc is the total variable cost ( $\mathrm{N} / \mathrm{ha})$ being the cost of variable inputs, and BCR is the benefit cost ratio.

Multiple regression analysis was used to analyse the effect of inputs on cassava output. Three functional forms of linear, semi-log and double-log were fitted for the regression analysis. The significant $t$-values, magnitude of the coefficient of determination $\left(\mathrm{R}^{2}\right)$ and the significant values of the estimators were the criteria used in the selection of the lead equation, which was the linear form. The regression equation is specified explicitly following the ordinary least square approach and is stated thus:

$\mathrm{Y}=\boldsymbol{\beta}_{\mathbf{0}}+\boldsymbol{\beta}_{1} \mathrm{X}_{1}+\boldsymbol{\beta}_{2} \mathrm{X}_{2}+\boldsymbol{\beta}_{3} \mathrm{X}_{3}+\boldsymbol{\beta}_{\mathbf{4}} \mathrm{X}_{4}+\boldsymbol{\beta}_{5} \mathrm{X}_{5}+\boldsymbol{\beta}_{6} \mathrm{X}_{6}+\boldsymbol{\beta}_{7} \mathrm{X}_{7}+\mu$.

Where, $Y$ is the output of cassava production $(\mathrm{kg}), \mathrm{X}_{1}$ is the Quantity of inorganic fertilizer $(\mathrm{kg} / \mathrm{ha}), \mathrm{X}_{2}$ is the quantity of herbicides/ha (litres), $X_{3}$ is the quantity of fungicides/ha (litres), $X_{4}$ is the farm size (ha), $X_{5}$ is the hired labour in manday, $\mathrm{X}_{6}$ is the family labour in manday, $\beta_{0}$ is the intercept or constant term, $\beta_{1}-\beta_{6}$ are the coefficients of the parameters estimate, and $\mu$ is the error term. Manday is the unit of measurement of labour per day. children age 7-14 years are accorded 0.5 of adult male equivalent, female adults of 1546years are accorded 0.75 and male adults of 15-64years are accorded 1.00.

\section{Results and Discussion}

\subsection{Determinants of Cassava Production}

Multiple regression analysis was used to determine the variables affecting cassava production in the study area as shown in Table 1. Cassava output was regressed on fertilizer quantity, farm size, herbicide applications, fungicides, hired labour, and family labour. The linear functional form was chosen of the three forms fitted for the analysis. The significant t-values, magnitude of the coefficient of determination $\left(\mathrm{R}^{2}\right)$ and the significant values of the estimators were the criteria used in the selection. All variable inputs used except fungicide were significant at different levels of significance between 1\% and $10 \%$ (Table 1). The result indicates that herbicides is important at the production stage. Similarly, family labour contribution through participation at different stages of production activities and processing of harvested produce cannot be overemphasised in cassava sub sector. The coefficient of fungicide was not significant probably due to the fact that it had a negligible impact on output produced. Hence, many farmers deemed it unnecessary to use it in most of the farm. The result is similar to that of [14] that emphasised that fertilizer application and household size are significant factors for cassava enterprise thereby improving rural livelihood and food security of the nation.

Table 1 Result of ordinary least square multiple regression analysis

\begin{tabular}{cccc}
\hline \hline Variable & Coefficient & Standard Error & T value \\
\hline Constant & 5.230577 & 1.372048 & 3.81 \\
Fertilizer & 9.793542 & 1.858399 & $5.27^{* * *}$ \\
Herbicide & 0.4488473 & 0.2422905 & $1.85^{*}$ \\
Fungicide & 0.1771383 & 0.1547023 & 1.15 \\
Farm Size & 0.7918113 & 0.1100063 & $7.20^{* * *}$ \\
Hired labour & 1.393661 & 0.2703595 & $5.15^{* * *}$ \\
Family labour & 0.3947081 & 0.2212705 & $1.78^{*}$ \\
$\mathrm{R}^{2}$ & 0.8509 & & \\
Adjusted $\mathrm{R}^{2}$ & 0.7614 & & \\
\hline \hline
\end{tabular}




\subsection{Profitability Analysis}

Budgetary analysis (Gross margin) was used to determine the profitability level of the cassava farmers in the study area as presented in Table 2 . The result showed that the total variable cost per hectare by cassava farmers was $\$ 17,980.66$ and total revenue was $\$ 42,729.94$ as stated in Table 2 . Thus, the gross margin obtained was $\$ 24,749.28(\$ 65.30) *$ per hectare. It implies that average cassava farmer in the study area earned gross profit of $24,749.28$ per hectare at the end of the season. On the other hand, the benefit cost ratio was of 2.38. It implies that for every 1 invested by the farmers in cassava production, 1.38 was realised in return. It can therefore be concluded that cassava production in Irepodun LGA, Kwara state, Nigeria was profitable. The result is in consonant with [15] that established that cassava production in Nasarawa state is profitable when the rate of return is found to be $153 \%$.

Table 2 Result of gross margin analysis

\begin{tabular}{ccc}
\hline \hline Items & $\begin{array}{c}\text { Cost } \\
(\mathrm{N})\end{array}$ & $\begin{array}{c}\text { Total Return (TR) } \\
(\mathrm{N})\end{array}$ \\
\hline Yield (Total value of cassava produced) & & $42,729.94$ \\
Variable items & & \\
Planting operations & $4,510.76$ \\
Herbicide used & $1,490.62$ \\
Fertilizer & $5,932.49$ \\
Fungicide used & $1,021.00$ \\
Hired labour & $3,070.66$ \\
Family labour & 954.05 \\
Transportation & $1,001.08$ \\
Total Variable Cost (TVC) & $17,980.66$ \\
Gross margin (GM) $=(\mathrm{TR}-\mathrm{TVC})$ & $24,749.28$ \\
Benefit Cost Ratio $=(\mathrm{GM} / \mathrm{TVC})$ & 1.38 \\
\hline \hline Note: $\$ 1=$ N379 (Source: Central Bank of Nigeria accessed November 11, 2020) \\
3.3. Constraints Analysis
\end{tabular}

Problems and constraints faced by cassava farmers militating against the increase in production are presented (Table 3). The results gathered were ranked and it showed that high cost of transportation $(89.4 \%)$, cost of production (42.3\%), lack of linkages with agro-markets (34.6\%), non-availability of improved cultivars $(24 \%)$ and inadequate investment capital $(15.4 \%)$ are the major factors hindering investors in cassava business enterprise. Corroborating this finding, [16] asserted that enabling production facilities, viable market channels and favourable working capital should be provided to stakeholders in tropical agricultural industry in order to maximise its growth potential, human and animal food enrichment, economic and industrial benefits.

Table 3 Result of Farmers Constraints on Cassava Production

\begin{tabular}{cccc}
\hline \hline Major Constraints & Frequency & Percentage (\%) & Rank \\
\hline Expensive Transportation & 93 & 89.4 & 1 \\
High cost of production & 39 & 37.5 & 2 \\
Market linkages hindrance & 36 & 34.6 & 3 \\
Lack of improved cultivars & 25 & 24 & 4 \\
Lack of capital & 16 & 15.4 & 5 \\
\hline \hline
\end{tabular}

Note: Multiple responses allowed

\section{Conclusion and Recommendations}

This study has proven the importance of cassava in rural areas particularly for farmers in Irepodun local government area, Kwara state, Nigeria. Cassava production has the potential to stabilise the rural economy, increase household income and boost foreign exchange earning of the nation if fully harness. This research concluded that cassava enterprise is profitable and capable of providing the necessary impetus for the current agricultural revolution strategy aimed at diversifying the economy. Based on the research findings, the study recommends as follows:

(a) good road network should be provided through public-private interventions and concessions in order to reduce hardship of investors in cassava enterprise arising from high cost of transportation due to bad road network;

(b) cost of cassava production can be reduced through provision of input subsidies such as herbicides and fertilizers for cassava farmers at affordable rate; 
(c) universities and research institutes should collaborate and intensify efforts in the development of improved varieties, the outcomes of such research should be made available and accessible through visible extension specialist in the agricultural value chain to farmers; and

(d) flexible loan and grant should be provided to small and medium enterprises (SMEs) in the cassava revolution industry so as to boost production for export thereby curbing negative effect of low capital. The current anchor borrow scheme by Central Bank of Nigeria should be sustain and other related windows should be set up.

\section{Conflict of Interests}

The authors declare that there is no conflict of interests regarding the publication of this paper.

\section{ORCID}

S. O. Sanusi (D) https://orcid.org/0000-0002-0531-643X

\section{References}

[1] A. Ikelegbe, "The economy of conflict in the oil-rich Niger Delta region of Nigeria," Nordic Journal of African Studies, vol. 14, no. 2, pp. 208-234, 2005.

[2] D. Byerlee, A. F. Garcia, A. Giertz, and V. Palmade, Growing Africa unlocking the potential of agribusiness, Washington, DC: The World Bank, pp. 35-39, 2013

[3] S. A. Adewuyi, A. M. Shittu, O. E. Fapojuwo, and S. H. Sowemimo, "Economics of labour use in selected food crop farming in Ogun State, Nigeria," Asian Journal of Agriculture and Rural Development, vol. 4, pp. 177-187, 2014.

[4] A. A. Adenle, L. Manning, and H. Azadi, "Agribusiness innovation: a pathway to sustainable economic growth in Africa," Trends in Food Science \& Technology, vol. 59, pp. 88-104, 2017.

[5] M. C. Nwike, T. O. Okoli, P. Oghenehogagame, and C. O. A. Ugwumba, "Economic efficiency and returns to scale of cassava production in southeast Nigeria," Int. Journal of Agriculture Innovations and Research, vol. 6, no. 1, pp. 23192330, 2017.

[6] International Institute for Tropical Agriculture (IITA), Starting a cassava farm, Ibadan, Nigeria: IITA Press, 2005.

[7] J. Babatunde, Value addition key to cassava revolution in Nigeria, Vanguard Newspaper, September 20, p. $16 ., 2011$.

[8] M. C. Nwike, "Investments and profitability in cassava enterprise in Nigeria," Nigeria Vocational Association (NVA), Book of Reading, vol. 3, no. 1, pp. 1-7, 2010.

[9] OECD-FAO, Overview of the OECD-FAO Agricultural Outlook 2015-2024, http://www.fao.org/3/ai4738e.pdf [Accessed July 31, 2016].

[10] Federal Ministry of Agriculture and Rural Development, The Green Alternative. Agricultural Promotion Policy 20162020. Building on the Successes of the ATA, Closing Key Gaps. Policy and Strategy Document, pp. 11-17, 2016.

[11] Y. A. Awoyinka, "Effect of presidential initiatives on cassava, production efficiency in Oyo state-Nigeria," Ozean Journal of Applied Sciences, vol. 2, no. 2, pp. 185-193, 2009.

[12] S. A. Alamu, "Constraints in the application of biotechnology to cassava production in Nigeria," Academic Journal of Interdisciplinary Studies, vol. 2, no. 10, pp. 105-117, 2013.

[13] National Population Commission (NPC), Population and housing census enumerators manual, Federal Republic of Nigeria, National Population Commission, Nigeria, pp. 1-16, 2006.

[14] N. P. Chikezie, D. F. Omokore, J. G. Akpoko, and J. Chikaire, "Factors influencing rural youth adoption of cassava recommended production practices in Onu-Imo local government area, Imo state, Nigeria," Greener Journal of Agricultural Sciences, vol. 2, no. 6, pp. 259-262, 2012.

[15] D. B. Zaknayiba, A. O. Agwale, and D. Bello, "Profitability analysis of cassava production in Wamba local government area of Nasarawa state, Nigeria," Production Agriculture and Technology, vol. 10, no. 2, pp. 218-224, 2014.

[16] H. C. J. Godfray, J. R. Beddington, I. R. Crute, L. Haddad, D. Lawrence, J. F. Muir, and C. Toulmin, "Food security: the challenge of feeding 9 billion people," Science, vol. 327, pp. 812-818, 2010. 